\title{
Black tax: An international exploratory study in the South African context
}

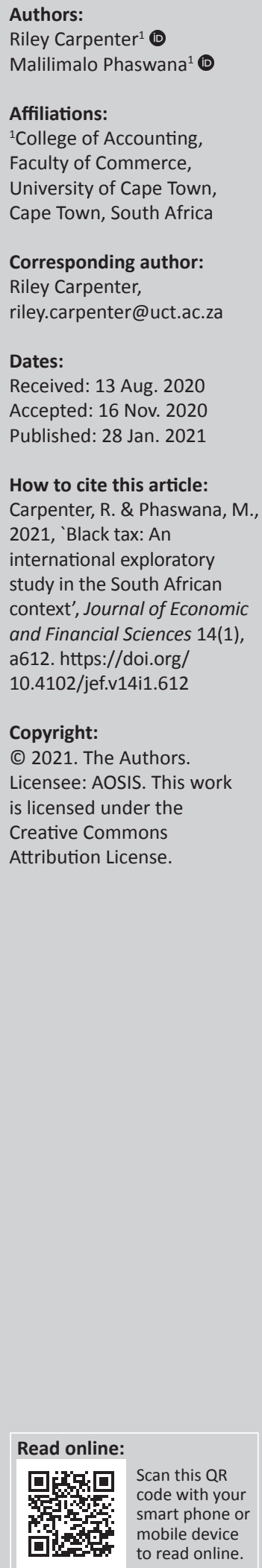

Orientation: South Africa is a country where the vast majority of residents experience inequality, poverty and deprivation on a daily basis. For many black South Africans, their experience includes the expectation to financially support extended family.

Research purpose: This 'black tax' provides the government with an opportunity to redistribute wealth through taxation provisions. The study's purpose is to consider whether South African taxation legislation currently provides for black tax and if not, to provide suggested improvements.

Motivation for the study: Whilst South Africa already has a social grant system in place, there is a need to account for varying levels of taxpayer responsibility and to encourage less dependence on the government.

Research approach/design and method: Using a doctrinal research methodology, the authors collated relevant legislation and judicial precedents applied in South Africa with respect to supporting extended family and compared these to the taxation systems in the United States of America (USA), Brazil and Nigeria.

Main findings: The findings indicate that the current South African taxation legislation does not provide for supporting extended family, including black tax, and the US dependent exemption or rebate is a potential option for consideration in South Africa.

Practical/managerial implications: Taxpayers should encourage the South African government to develop a discussion document to encourage wider discourse.

Contribution/value-add: The study makes an important contribution to the debate on changing taxation legislation to ensure income and wealth redistribution.

Keywords: black tax; private transfers; dependent exemption; dependent rebate; wealth tax; redistribution; South Africa.

\section{Introduction}

Inequality, poverty and deprivation are a part of black South African life (Gradín 2013; Idahosa \& Van Dijk 2016). Encouraging economic growth following the advent of democracy in 1994 has done little to reduce this inequality. In fact, studies have shown that after attaining democracy, inequality in South Africa has tended to increase (Acemoglu et al. 2013).

A harsh reality of many black South Africans is the financial burden of having to support direct and extended family. This is colloquially known as 'black tax', and evidence suggests that it may help lower inequality in South Africa (Mangoma \& Wilson-Prangley 2019).

In South Africa, the personal income tax is progressive in nature, and in 2017-2018, it accounted for $38 \%$ of the tax collected by government. In contrast, the value-added tax (VAT) is regressive, accounting for $24 \%$ of tax collected in the same period (Statistics South Africa 2019). It therefore makes sense to investigate whether or not taxation, and more specifically the deductibility of black tax, can be used as a mechanism for bringing about redistribution - firstly in the taxation system and secondly in the country as a whole.

This study focuses on the deductibility, exemption or tax credit of black tax in the context of South African legislation. The taxation of private transfers in three other countries is then investigated to see whether any suggested improvements could be made to South African law. Lastly, the study considers whether these other countries' treatment of private transfers could be adapted for South Africa. 
The findings indicate that the taxation system of the United States of America (USA) is a good benchmark for South Africa. The system has a strong rationale and has been in existence for many decades. The need that prompted the introduction of the tax in the USA currently exists in South Africa, and there is reason to consider the introduction of a similar provision in the South African tax system.

This study begins by reviewing previous research on inequality, black tax and taxation in general, with particular reference to the South African context. Thereafter, relevant literature is reviewed, followed by a description of the research method. Next, relevant South African legislation is examined, together with other countries' treatment of private transfers. Lastly, conclusions are drawn on application in the South African context.

\section{Literature review}

\section{Racial inequality in South Africa}

Despite apartheid having come to a formal end in 1994, South Africa stands out in the world as one of the countries with the highest levels of racial inequality (Idahosa \& Van Dijk 2016). The 2014 estimate of South Africa's Gini coefficient, as published by the World Bank, was 63 - the second highest in the world after Sierra Leone (The World Bank 2019). In addition to racial inequality, black South Africans also face higher levels of poverty and deprivation than white South Africans (Gradín 2013), with the average white South African's income being eight times that of his or her black counterpart.

The cause of racial inequality is South Africa's long history of European colonisation and apartheid, which resulted in black South Africans being forced into economic disadvantage (Leibbrandt, Finn \& Woolard 2012). Tregenna (2012) shows that inequality and unemployment are interlinked, making it necessary for employment to increase if inequality is to decrease. South Africa's unemployment rate is very high at $29 \%$, but whilst the portion of white unemployed individuals is $8 \%$, the black African equivalent is $32 \%$ (Statistics South Africa 2020). Demographic differences, most notably household size, also play a determining role in racial inequality (Gradín 2013). Black households generally have a larger number of members compared to white households (Statistics South Africa 2016). This results in a greater financial burden placed on black households, as more resources are needed to provide for healthcare, schooling and food.

Although a sizeable reduction in inequality would have been expected given the growth that South Africa has experienced since the end of apartheid, this has not been the case. Akanbi (2016) argues that this 'triple challenge' trend (growth, poverty and inequality) occurs when policies aiming to promote the growth of a country in fact lead to increased inequality and poverty. To spur growth, countries need to focus on developing economic hubs and projects that encourage foreign investment. However, it is unlikely that the poor would be adequately represented in such endeavours, and they would consequently lose out (Akanbi 2016).

Acemoglu et al. (2013) take the argument a step further by reasoning that inequality tends to increase after democratisation, when an economy has undergone significant structural transformation, where land inequality is high and the gap between the middle class and the poor is very small. Despite government efforts to redistribute land fairly, land inequality continues to be very high in South Africa. The country has not yet undergone significant structural transformation since its democratisation in 1994, and the gap between the poor and the middle class persists (Finn, Leibbrandt \& Woolard 2013). Therefore, the trend that South Africa appears to have followed is that inequality decreased slightly after democracy, before increasing again because of the unequal distribution of resources obtained during economic development.

\section{What is black tax?}

Limited research has been performed on black tax. Whiting (2009) broadly describes it as a cost that is incurred by black people because of circumstances not experienced by their white counterparts. In the context of this study, 'black tax' relates to the financial burden borne by black South Africans, who have to pay or transfer money and other goods to support their direct and indirect family. This is an important concept because of the scale of the support required, given the large size of black households (Gradín 2013) and the extent of poverty experienced by these individuals (Leibbrandt et al. 2012).

Maitra and Ray (2003) attribute the long tradition of such private transfers to the history of black South Africans. During the period of British colonialism, and especially later during apartheid, black South Africans were forcibly moved and restricted to economically inactive 'homelands' (Beck 2013). This forced many male black South Africans to migrate to the economic hubs of South Africa, such as Johannesburg and Cape Town, in search of jobs. Rural households in these homelands would eventually come to be dependent on transfers of money by these migrant breadwinners as a significant source of income (Maitra \& Ray 2003).

\section{The rationale of black tax}

Molina (2013) attributes the altruistic nature of black tax to an evolutionary process known as 'Hamilton's rule'. Hamilton's rule states that an altruistic behaviour, such as making a private transfer (black tax), will be advantageous if the costs to the individual are less than the benefits generated for the people helped, correlated by the degree of familiarity between them (Hamilton 1964; Okasha \& Martens 2016). The familiarity between black South Africans and their extended family is therefore a key determining factor in these transfers. 
It can be argued that familiarity between members of the same family is strong everywhere in the world; however, it is especially significant in poorer countries like South Africa (Cox \& Fafchamps 2007). The reason for this is the lack of a social safety net provided by the government. Although South Africa has one of the most extensive welfare programmes in the world (Potts 2012), many black South Africans continue to live below the poverty line (Akanbi 2016). The consequence of this is that there is a reduced notion of autonomy, as poor families will often require the assistance of other family members to provide for their basic needs.

\section{Taxation as a mechanism for redistribution}

Countries with high levels of inequality, such as South Africa, would be expected to make extensive use of taxation as a means of redistribution, but the opposite is actually true (De Freitas 2012). Although personal income tax is progressive, this is offset by a regressive VAT. Personal income tax is progressive because the higher the individual's income, the higher their effective tax rate, thereby encouraging a redistribution from high-income individuals to low-income individuals. The VAT is a regressive tax mechanism because a larger proportion of the income of low-income individuals, in comparison to high-income individuals, are spent on VAT. The VAT was the second largest contributor to tax revenue in the 2018 fiscal year, which demonstrates the dependence of the state on this tax instrument (Statistics South Africa 2019). This shows that there is still scope to use taxation as a mechanism for redistribution, especially because the tax associated with private transfers is levied by the largest form of tax - personal income tax.

Durante, Putterman and Van der Weele (2014) set out the following three arguments for using taxation as a means of redistribution. Firstly, in a country like South Africa, where the majority of citizens are disadvantaged by inequality (Acemoglu et al. 2013), resources can be shifted from the rich minority to the poor majority. Secondly, redistribution through taxes acts as insurance for all citizens by giving them assurance that they will be provided for if their future incomes deteriorate. Thirdly, redistribution can serve as a form of bringing justice to countries where inequality is deemed to be unfair, such as South Africa, where inequality stems from apartheid.

\section{Research design}

This qualitative study uses a doctrinal research methodology and document analysis to interpret the results. Document analysis is the evaluation of all forms of documents (Bowen 2009). Textual analysis is also used, focusing on the meaning that can be extracted from documents (De Vos et al. 2011). Thus, the study analyses relevant sections of the Income Tax Act no. 58 of 1962 (as amended), as well as judicial precedents.

The taxation systems of three other countries are also examined. The first country is the USA, which has the largest economy in the world, measured in terms of gross domestic product (GDP) (International Monetary Fund 2019) and the largest tax system in the world measured in terms of collected revenue (Central Intelligence Agency 2020). This makes it a robust benchmark against which to evaluate other tax systems.

The second country is the Federative Republic of Brazil (Brazil). Brazil was selected because it is very similar to South Africa in terms of economic profile, level of inequality and political situation (Narayan \& Narayan 2013).

The Federal Republic of Nigeria (Nigeria) is the third country. Nigeria was selected as it is also an African country, with an economy of similar size to South Africa measured in terms of GDP (International Monetary Fund 2019).

Lastly, application to the South African context is considered.

\section{Current treatment of private transfers under the Income Tax Act}

Before analysing the tax treatment of private transfers between households, the study considers the current tax treatment of these transactions in South Africa. The tax treatment is governed by the Income Tax Act no. 58 of 1962 (as amended), as this is the primary legislation that administers the normal tax payable by any person. The focus of this study is to analyse the transaction from the point of view of the person making the transfer - the transferor.

Amounts are deductible from the income of any person if they are eligible for deduction under Section 11 of the act and if the deduction is not specifically disallowed, under Section 23. In addition, the taxpayer may be entitled to a rebate (a reduction in the tax liability), if the requirements of sections $6 \mathrm{~A}$ or $6 \mathrm{~B}$ apply.

\section{Deductions}

Amounts can be deducted from the income of a taxpayer if there is a special deduction in Section 11 of the act allowing for the deduction or if the nature of the expenditure is such that it satisfies the criteria for a general deduction under Section 11(a). The preamble to Section 11 requires the taxpayer to carry on a trade in order for a deduction to be considered. Trade is defined in Section 1 as including every profession, trade, business, employment, calling, occupation or venture, including the letting of any property and the use of or the grant of permission to use any trademark, copyright or any other property that is of a similar nature.

This requirement indicates that the transferor would have to have derived the pre-transfer amount from an activity that qualifies as a trade. A deduction would therefore not be considered if the amount were derived by the transferor from other means such as pensions or annuities or if the amount were derived from a private transfer. 


\section{Special deductions - Section 11}

There is currently no special provision in Section 11 that allows for the deduction of private transfers or any amounts used to support dependence. Therefore, one has to look to the general deduction under Section 11(a) to consider deductibility.

\section{General deduction}

The general deduction under Section 11(a) provides that expenditure and losses must be actually incurred in the production of the income, as long as such expenditure and losses are not of a capital nature.

The key consideration here is whether or not the transfer of the amount is incurred in the production of income. In order for the transfer to be incurred in the production of income, it would have to be incurred for the purpose of producing the pre-transfer amount (Port Elizabeth Electric Tramway Company Ltd v CIR (1936) CPD 241, 8 SATC 346), and it would have to be an inevitable or necessary concomitant for the taxpayer to incur this amount in order to earn the pre-transfer amount (COT $v$ Rendle (1965) SA 59, 26 SATC 326).

The purpose of private transfers is, by nature, to provide financial support to the recipients of the amount. Incurring these transfers does not contribute to the income-earning potential of the taxpayer. Furthermore, the transfer of these amounts to the transferee is not necessary in order for the transferor to earn the pre-transfer amount. This is because the transfer transaction is a separate activity from whatever activity was carried on to earn the income.

\section{Section 23(a), (b) and (g)}

Section 23(a) of the act prohibits the deduction of any costs incurred in the maintenance of a taxpayer, his or her family or establishment. Private transfers are made to provide financial support for members of the transferor's immediate or extended family; therefore, their deduction would be not be allowed.

Section 23(b) of the act prohibits the deduction of any private or domestic expenses. Private transfers are of a private nature because they are not made in the carrying on of any trade.

Section 23(g) prohibits the deduction of any amounts insofar as they are not expended for the purposes of trade. Private transfers are not expended for the purposes of trade because of the absence of a causal link between the income-earning activities of the transferor and the private transfer transaction. The deduction of transfer amounts would therefore be prohibited under this section.

\section{Rebates}

The act provides for two rebates, being a reduction in tax payable, in the form of a medical aid scheme fees tax credit and an additional medical expenses tax credit.
The Section 6A medical aid scheme fees tax credit applies to fees paid by a taxpayer to a medical aid scheme, in respect of the taxpayer or their dependent. The credit amounts to R310 per month for the taxpayer, R310 per month for the first dependent and R209 per month for each additional dependent for the 2020 year of assessment (Republic of South Africa 2020). A dependent is a taxpayer's spouse, child or another family member for whom they are caring.

The Section 6B additional medical expenses tax credit applies both to additional medical expenses and a portion of the medical aid scheme fees that exceeds a certain amount of the Section $6 \mathrm{~A}$ rebate. The medical costs paid by the taxpayer can be on behalf of either the taxpayer or a dependent. If the taxpayer is under the age of 65 and they, their spouse or child do not have a disability, the credit is further limited by an excess above $7.5 \%$ of taxable income and a smaller inclusion rate.

\section{Conclusion}

The South African Income Tax Act only caters for the medical support of the taxpayer and their dependents. Although this is a good start, there is currently no basis for which private transfers as a means of general financial support (or other specific support) can be deducted or allowed as a rebate against the tax payable of an individual.

\section{Analysis of alternative treatment of private transfers}

Aside from raising government revenue, taxation systems around the world are used to achieve certain objectives, from influencing specific behaviours to correcting market imperfections (Bird \& Zolt 2014). In the South African tax system, the deductions available to individuals who do not carry on a trade in their own name are extremely limited because of the focus on only granting deductions for expenditure incurred to earn taxable income (Haupt 2019). As concluded previously, it follows that the South African tax system does not provide relief for the financial support of dependents through private transfers or otherwise.

The aim of this part of the study is to analyse the taxation systems of other countries, specifically the USA, Brazil and Nigeria, which allow for the exemption or deduction of expenses relating to the financial support of dependents. The purpose of this analysis is to establish whether similar exemptions could be incorporated into the South African taxation system.

\section{Mechanics of tax systems United States of America}

Taxation in the USA is governed by Title 26 of the United States Code, which is also known as the US Tax Code. There are four provisions in the US Tax Code that provide relief for the financial support of dependents through the reduction of taxable income. These are the dependent tax credit, the 
medical expenses deduction, the student loan interest deduction and the qualified tuition deduction.

\section{Who are dependents?}

The US Tax Code allows for two groups of people to be qualified as dependents of a taxpayer: qualifying children and qualifying relatives. Because this study concerns the financial support of extended family, the analysis focuses on qualifying relatives. Section 152(d) of the US Tax Code defines a qualifying relative as an individual who bears a relationship to the taxpayer, whose gross income is below an exemption amount (as defined in Section 151(d)), with respect to whom the taxpayer provides more than half of the individual's support for the calendar year.

An individual bears a relationship to the taxpayer if the individual is (1) a child (or a descendant thereof); (2) a brother or sister (including step-relationships); (3) the father or mother (or ancestor of either); (4) a stepfather or stepmother, a son or daughter of a brother or sister of the taxpayer; (5) a brother or sister of the father or mother of the taxpayer; (6) a son-in-law, daughter-in-law, father-in-law, mother-in-law, brother-in-law or sister-in-law; or lastly, (7) an individual (excluding spouses) who has the same principal place of abode as the taxpayer and is a member of the taxpayer's household.

Therefore, who qualifies as a dependent, as defined, is slightly narrower in the USA compared to South Africa as South Africa includes any family member for whom the taxpayer is caring.

\section{Dependent tax credit}

Section 151(c) of the US Tax Code used to allow for an exemption from the income of a taxpayer for each of their dependents. The exemption equalled $\$ 4050$ for the 2017 tax year (US Department of Treasury, Internal Revenue Service 2018). The taxpayer lost a certain percentage of their exemption once their gross income was above a certain threshold. This was to ensure that the exemption benefitted only low-income families who needed it the most. The threshold for the 2017 tax year was equal to $\$ 261500$, and any taxpayer with a gross income above $\$ 384000$ lost out on the dependent exemption completely (US Department of Treasury, Internal Revenue Service 2018).

The Tax Cuts and Jobs Act of 2017 (Pub.L. 115-97) amended the US Tax Code, which included eliminating the dependent exemption and introducing a credit against tax payable. Whilst Section 24 of the US Tax Code is named the 'child tax credit', the new act introduced Section 24(h), 'Special rules for taxable years 2018 through 2025'. Section 24(h) provides for a tax credit of $\$ 500$ for each dependent, as defined above, on top of a tax credit of $\$ 2000$ for a qualifying child of the taxpayer. The Tax Cuts and Jobs Act provides for economic stimulation in the short term, but because of many uncertain factors, including the responses of other countries, the US Federal Reserve Board and future US Congresses, the long- term effect cannot be quantified (Gale et al. 2018). Most families' tax benefits increased slightly because of the Tax Cuts and Jobs Act. This was mainly a result of the decrease from the elimination of the exemption being offset by a greater standard deduction and the dependent tax credit (Tax Policy Centre 2020). In addition, the amendment resulted in easier compliance as itemised deductions were significantly reduced (Tax Policy Centre 2020).

\section{Medical expenses deduction}

Section 213 of the US Tax Code allows for the deduction of non-recoverable expenses relating to the medical care of the taxpayer, as well as the taxpayer's dependents. A wide range of medical expenses qualify for this deduction, including fees relating to hospitalisation, drug rehabilitation, transport for medical treatment and insurance premiums (US Department of Treasury, Internal Revenue Service 2020a). The medical expenses allowed for a deduction are first reduced by $7.5 \%$ of the taxpayer's gross income. Whilst South African taxpayers also have a tax benefit for medical costs, it is in the form of rebates, in sections $6 \mathrm{~A}$ and $6 \mathrm{~B}$ of the Income Tax Act.

\section{Student loan interest deduction}

Taxpayers with a gross income of less than $\$ 65000$ are allowed a deduction relating to interest on student loans for themselves or their dependents for tertiary education under Section 221 of the US Tax Code. The deduction is allowed only if the loan is taken specifically to fund qualifying educational expenses. Qualifying expenses include tuition, accommodation, transportation and learning material (US Department of Treasury, Internal Revenue Service 2020b).

\section{Tuition and related expenses deduction}

A deduction of qualifying tuition and related expenses incurred by the taxpayer or the dependents of the taxpayer is allowed under Section 222 of the US Tax Code. Qualifying educational expenses are the same as those allowed for the student loan interest deduction. The deduction is limited to $\$ 4000$ for taxpayers with gross income not exceeding \$65000 and $\$ 2000$ for taxpayers with gross income not exceeding $\$ 80$ 000. It should be noted, however, that the deduction is only available for tertiary education and is terminated for tax years beginning after 31 December 2020. Whilst there is a potential deduction related to learnership allowances under Section 12(h) of South Africa's Income Tax Act, the deduction is for the benefit of the employer.

\section{Federative Republic of Brazil}

Article 146 of the Constitution of the Federative Republic of Brazil allows for the personal income taxation of individuals to be administered through the Código Tributário Nacional (National Tax Code). The National Tax Code has three provisions that allow for the reduction of taxable income in relation to the financial support of dependents by a taxpayer: the dependent exemption, the medical exemption and the educational exemption. 


\section{Who are dependents?}

The National Tax Code allows for the following individuals to qualify as dependents of a taxpayer: (1) spouse; (2) companion or partner, provided that they have been living together for more than 5 years, or a shorter period if the union resulted in a child; (3) daughter, son, stepdaughter or stepson, up to 21 years, or any age if incapacitated physically or mentally to work; (4) child, up to 21 years, whom the taxpayer educates and of whom the taxpayer holds legal custody; (5) brother, grandson or great-grandson, without parental breadwinner, up to 21 years, provided that the taxpayer holds legal custody, or any age if incapacitated physically or mentally to work; (6) parents, grandparents or great-grandparents, provided they do not receive income higher than a monthly exemption limit; or (7) a person absolutely incapable of earning income, of whom the taxpayer is guardian or trustee. Similar to the USA, who qualifies as a dependent, as defined in Brazil, is slightly narrower than in South Africa, as South Africa includes any family member for whom the taxpayer is caring.

\section{Dependent deduction}

The National Tax Code allows for a deduction from taxable income for every dependent of the taxpayer under Article 4 III (i). The deduction is equal to BRL 2275 for the 2019 tax year (Deloitte 2019).

\section{Medical expenses deduction}

Article 8 II (a) of the National Tax Code allows for the deduction of medical expenses incurred by the taxpayer for his or her own benefit or for the benefit of his or her dependents. The medical expenses are limited to payment actually made to medical practitioners and hospitals. This means that no deductions are available for medicine or transport. There is no limit as to the amount of the deduction that may be claimed for medical expenses. Therefore, the deduction could be of greater benefit to the taxpayer than South Africa's Income Tax Act sections 6A and 6B rebates against tax payable for medical costs.

\section{Educational expenses deduction}

Article 8 II (b) of the National Tax Code allows for the deduction of expenses incurred for the education of the taxpayer and the dependents of the taxpayer. Only expenses incurred through the payments to educational institutions qualify for this deduction. A wide range of educational institutions are allowed, starting from nursery schools and preschools all the way to tertiary education institutions and other specialised or vocational education institutions. The deduction allowed is limited to BRL 3561 for the 2019 tax year (Deloitte 2019). No deduction is allowed for accommodation or learning material.

\section{Federal Republic of Nigeria}

The personal income taxation in Nigeria is administered through the Personal Income Tax Act (PITA). The PITA has two separate provisions relating to the financial assistance of dependents, each with their own criteria of who can qualify: (1) the minor's exemption and (2) the incapacitated person's exemption.

\section{Minor's exemption}

Section 33(3)(b) of the PITA allows for an exemption of N2500 for each unmarried child whom the taxpayer maintains. The child must be under the age of 16, receiving full-time education or serving articles for a trade or profession to qualify for the deduction. A taxpayer can claim this deduction for a maximum of four children. There is no additional deduction for educational or medical expenses for these dependents.

\section{Incapacitated persons deduction}

A deduction is allowed for expenses relating to the maintenance of a close relative who is incapacitated by old age or infirmity under Section 33(3)(c) of the PITA. This deduction is limited to relatives who do not have income in excess of N1000, and all the deductions claimed by the taxpayer under this section may not exceed N4000.

\section{Rationale for dependent exemptions, deductions and/or credits}

Seltzer (1968) contends that there are two primary purposes for a tax system to provide for an exemption for taxpayers. Firstly, an exemption could exclude persons whose income is at the level required to survive. Secondly, an exemption could exclude all incomes required for the need to survive.

A progressive tax system needs to account for the varying levels of responsibility across families of different sizes. Fleurbaey, Hagneré and Trannoy (2014) point out that the financial burden on households increases as the household size increases. The result is that a certain level of income that could comfortably support a small household could leave a larger household below the poverty line. It therefore would not be equitable for all individuals to be taxed on the same basis regardless of the number of people they are supporting on their income.

Investing in children is investing in the citizens of tomorrow, who will eventually better the world for the current taxpayers. Kornrich and Furstenberg (2013) argue that spending on children is one of the most effective ways in which parents can invest in human and cultural capital. This kind of expenditure includes high-quality education, healthy food and other enriching experiences such as visits to the zoo or museums. It would therefore make sense for these expenditures to be incentivised through taxes by reducing the financial burden that comes with caring for children.

Duncan, Magnuson and Votruba-Drzal (2016) observe that families that are economically disadvantaged experience greater levels of stress in their everyday lives than their more 
affluent counterparts. This not only hampers childhood development, but stressful circumstances in the family also deplete the cognitive resources of adults (Spears 2011). Making economic decisions under stressful circumstances reduces the adult's ability to control their own behaviour and pursue longer term goals (Spears 2011). This would be devastating for any society as it could easily lead to social problems such as crime and redundancy.

Society, at least in the USA, is starting to distinguish between the poor who are deserving of welfare and those who are not (Moffitt 2015). In this instance, the poor who are deserving are defined as those who work, who are married and who have children. People are therefore more willing to pay taxes in order to support individuals who are not only making an effort to earn their own income but are also responsible for other individuals such as children and the elderly. Society is also willing to provide welfare to the elderly on the premise that they receive the support when they age (Svallfors 2012). Aging is an eventuality for all individuals; therefore, welfare systems for the elderly are partially seen as an investment in society.

Madden and Savage (2014) have found that social welfare plays a pivotal role in public policy, which results in the very poor being the most dependent on the state. It follows that if low-income households were not to get relief through tax exemptions, they would have to seek public support elsewhere. Social welfare through taxation is, however, preferred to welfare through transfers because taxation requires the beneficiaries of the welfare to work to earn the income (Fleurbaey et al. 2014).

\section{Objections against dependent exemptions}

One of the biggest arguments against personal exemptions is that low-income taxpayers benefit less from the exemption than high-income taxpayers (Maag 2013). The reason for this is that the exemption reduces taxable income by a fixed amount and that taxable income will be taxed at a progressive rate. Low-income taxpayers will therefore derive a benefit equal to the exemption amount multiplied by their low tax rate, whilst high-income taxpayers will receive a greater benefit as a result of their higher marginal tax rate.

Another consequence of this is that taxpayers who fall below the minimum tax threshold amount or who are pulled below the threshold by the exemption will only receive a limited benefit, if at all. It is therefore necessary for the taxpayer to be earning a certain amount of income in order to benefit from the exemption. This is not necessarily seen as a negative feature of the provision by general society and legislators. Maxfield (2013) has found that Americans favour welfare systems that also require beneficiaries to earn income. Such systems represent less of a handout and more of an incentive to help low-income earners lift themselves out of poverty whilst also spurring economic growth.
Another objection against the dependency exemption is that large families and their dependents are already demanding a lot from the state; therefore, the additional exemption would be overbearing (Seltzer 1968). The demands made of the state are in the form of public goods such as education, infrastructure, health and recreation, all of which are subsidised by the state using taxes collected from households of all sizes. This is contrary to the finding of Moffitt (2015), who argues that society is more sympathetic to the needs of taxpayers who bear the financial burden of supporting children and the elderly.

Seltzer (1968) also argues that the amount spent on dependents by taxpayers is optional, and taxpayers may derive other personal benefits from the financial support. This is likely to be the case because of the obligation for individuals to support extended families and even close friends whenever they can afford to lift them above the poverty line (Connidis 2015). However, whether or not the taxpayer actually discharges this obligation is very much dependent on multiple factors such as familial ties and the income gap between households.

\section{Conclusion}

The US Tax Code provides for a dependent tax credit and deductions for medical expenses, student loan interest and educational expenses. Whilst the dependent definition is slightly narrower than South Africa's, there are more tax benefits afforded to taxpayers. Brazil's National Tax Code allows for deductions for dependents and medical and educational expenses. Similar to the USA, a narrower definition of dependent is offset by additional tax benefits. However, there is difficulty in keeping track of the dependents in Brazil. Nigeria's PITA only provides for a minor's exemption and incapacitated persons' deduction. Therefore, Nigeria's tax benefits are limited.

The US taxation system has a robust mechanism for accounting for the number of dependents an individual has in determining their taxable income. South Africa only benefits from its slightly expanded definition of dependent for the purposes of the medical expenses rebates. Unfortunately, South Africa does not have any other tax benefits relating to supporting dependents or paying for education.

Therefore, the US system, especially the dependent tax credit, is a good benchmark to consider if a country such as South Africa were to introduce a similar system because it has a strong rationale backed by the general public and legislators. Notwithstanding changes in the recent past with some tax benefits shifting from an exemption to a tax credit, the US system has been in existence for many decades, demonstrating that it is sustainable and able to withstand various macroeconomic events. 


\section{Adaptability to the South African context}

To establish whether or not a taxation provision in the form of an exemption or a deduction is applicable to South Africa to address black tax, it is necessary to first determine whether the potential benefits and objections against these tax provisions would apply. The discussion then considers the necessity of introducing these welfare provisions into the South African taxation system, given that South Africa already has a social grant system in place. This is done by considering the welfare systems of the analysed countries and the additional role that tax provisions play.

\section{Need to account for varying levels of responsibility of taxpayers}

The key rationale for introducing a provision to address black tax is the notion that black South Africans earning a given amount of income have to discharge a greater amount of responsibility with it than their white counterparts. A contributing factor is household size (Idahosa \& Van Dijk 2016).

The 2016 Community Survey (implemented between each census) conducted by Statistics South Africa showed that the average white household had 2.7 members whilst the average black household had 3.3 members (Statistics South Africa 2016). These differences in household size can be attributed to higher fertility in black women compared with white women (Low et al. 2013) and result in a greater likelihood of black individuals needing to support extended family (Fingerman et al. 2011) as a result of their higher level of poverty (Taylor et al. 2013).

\section{Role of social welfare}

Although South Africa has an extensive welfare system in place, there is a large gap in the support for able-bodied, working-age adults who are unemployed (Seekings \& Moore 2013). South Africa's high unemployment rate of $29 \%$ is skewed towards black South Africans (Statistics South Africa 2020). The result is that unemployed individuals receive financial assistance from their nearest kin as dependents, with neither kin nor dependent receiving any support from a taxation or social welfare perspective (Klasen \& Woolard 2009). This is different from the three countries analysed above, where tax relief would be available for the person supporting the dependent.

\section{Need to encourage less dependence on the government}

The increased income earned by black South Africans after apartheid reduced their dependency on state-subsidised services (Seekings \& Moore 2013). Black individuals began entering the market for private education for their children, private healthcare for the elderly and other private goods. The salient fact here is that not only is the primary income earner less dependent on the state but the entire household has also experienced this shift.

Seekings and Moore (2013) further argue that increased household income increases the participation of household members in the labour market. The reason for this is that this income allows them to access different job markets that would otherwise have been inaccessible to them, had they been trapped in rural areas. Potts (2012) disagrees, arguing that increases in income, including through social grants, decrease labour force participation because more of their needs are met.

\section{Conclusion, limitations and areas for future research}

The preconditions that prompted the need for the dependent exemption, or tax credit, in the USA also exist in South Africa. Therefore, there is reason to consider the introduction of a similar provision in the South African tax system. This study is subject to quantitative limitations in determining the extent to which the South African legislation would affect tax liabilities. Access to quantitative data could allow for further research into this topic. In addition, other countries could be compared to South Africa, for example India, as a developing economy.

\section{Conclusion and recommendations}

Taxation provisions have been made by several countries to ensure the fairness of the income tax burden by taxing everyone based not only on their level of income, but also by taking into account their level of financial responsibility. The way in which these provisions are being carried out in other parts of the world shows that it is possible for South Africa to enact similar provisions to alleviate the effects of supporting both direct and extended family, which for a large proportion of South Africa's population includes black tax. Whilst there is some relief in the form of medical expense rebates, this is not sufficient in addressing the responsibility borne by taxpayers, especially black taxpayers, and the impact on the growing middle class in an unequal, impoverished South African society.

A provision that could be introduced to assist taxpayers who are responsible for the welfare of their family is either the old dependent exemption or the new dependent tax credit applied in the USA. Introducing such a provision would assist South Africa in addressing its high level of income and wealth inequality.

\section{Acknowledgements Competing interests}

The authors have declared that no competing interests exist.

\section{Authors' contributions}

All authors contributed equally to this work. 


\section{Ethical consideration}

Ethical clearance was not needed or required for the study and followed all ethical standards for carrying out research.

\section{Funding information}

The authors received no specific grant from any funding agency in the public, commercial or not-for-profit sectors.

\section{Data availability statement}

Data sharing is not applicable to this article as no new data were created or analysed in this study.

\section{Disclaimer}

The views and opinions expressed in this article are those of the authors and do not necessarily reflect the official position of the University of Cape Town.

\section{References}

Acemoglu, D., Naidu, S., Pascual, R. \& Robinson, J.A., 2013, Democracy, redistribution and inequality, National Bureau of Economic Research Working Paper Series, Cambridge.

Akanbi, O.A., 2016, 'The growth, poverty and inequality nexus in South Africa: Cointegration and causality analysis', Development Southern Africa 33(2) 166-185. https://doi.org/10.1080/0376835X.2015.1120654

Beck, R., 2013, The history of South Africa, 2nd edn., Greenwood, London.

Bird, R.M. \& Zolt, E.M., 2014, 'Redistribution via taxation: The limited role of the personal income tax in developing countries', Annals of Economics and Finance 15(2), 625-683.

Bowen, G.A., 2009, 'Document analysis as a qualitative research method', Qualitative Research Journal 9(2), 27-40. https://doi.org/10.3316/QRJ0902027

Central Intelligence Agency, 2020, The World Factbook, viewed 04 August 2020, from https://www.cia.gov/library/publications/the-world-factbook/geos/sf.html.

Connidis, I.A., 2015, 'Exploring ambivalence in family ties: Progress and prospects', Journal of Family and Marriage 77(1), 77-95. https://doi.org/10.1111/jomf.12150

COT $v$ Rendle (1965 SA 59)(26 SATC 326).

Cox, D. \& Fafchamps, M., 2007, 'Extended family and kinship networks: Economic insights and evolutionary directions', Handbook of Development Economics 4 3711-3784. https://doi.org/10.1016/S1573-4471(07)04058-2

Deloitte, 2019, International Tax: Brazil highlights, viewed n.d., from https://dits. deloitte.com/\#TaxGuides.

De Freitas, J., 2012, 'Inequality, the politics of redistribution and the tax mix', Public Choice 151(3-4), 611-630. https://doi.org/10.1007/s11127-010-9761-z

De Vos, A.S., Strydom, H., Fouche, C.B. \& Delport, C.S.L., 2011, Research at grass roots for the social and human service professions, 4th edn., Van Schaik, Pretoria.

Duncan, G.J., Magnuson, K. \& Votruba-Drzal, E., 2016, 'Boosting family income to promote child development', The Future of Children 24(1), 99-120. https://doi. org/10.1353/foc.2014.0008

Durante, R., Putterman, L. \& Van der Weele, J., 2014, 'Preferences for redistribution and perception of fairness: An experimental study', Journal of the European

Fingerman, K.L., VanderDrift, L.E., Dotterer, A.M., Birditt, K.S. \& Zarit, S.H., 2011 'Support to aging parents and grown children in black and white families', The Gerontologist 51(4), 441-452. https://doi.org/10.1093/geront/gnq114

Finn, A., Leibbrandt, M. \& Woolard, I., 2013, The middle class and inequality in South Africa, University of Cape Town, Cape Town.

Fleurbaey, M., Hagneré, C. \& Trannoy, A., 2014, 'Welfare comparisons of income distributions and family size: An individualistic approach', Journal of Mathematical Economics 51(1), 12-27. https://doi.org/10.1016/j.jmateco.2014.02.006

Gale, W., Gelfond, H., Krupkin, A., Mazur, M. \& Toder, E., 2018, Effects of the tax cuts and jobs act: A preliminary analysis, Tax Policy Centre, Washington, DC.

Gradín, C., 2013, 'Race, poverty and deprivation in South Africa', Journal of African Economies 22(2), 187-238. https://doi.org/10.1093/jae/ejs019

Hamilton, W.D., 1964, 'The genetical evolution of social behaviour. II', Journal of Theoretical Biology 7(1), 17-52. https://doi.org/10.1016/0022-5193(64)90039-6

Haupt, P., 2019, 'Individuals', in Notes on South African income tax, 38th edn., p. 232, H\&H Publications, Cape Town.

Idahosa, L. \& van Dijk, J., 2016, 'South Africa: Freedom for whom? Inequality, unemployment and the elderly', Development (Basingstoke) 58(1), 96-102. https://doi.org/10.1057/dev.2015.18
International Monetary Fund, 2019, World economic outlook database.

Klasen, S. \& Woolard, I., 2009, 'Surviving unemployment without state support: Unemployment and household formation in South Africa', Journal of African Economies 18(1), 1-51. https://doi.org/10.1093/jae/ejn007

Kornrich, S. \& Furstenberg, F., 2013, 'Investing in children: Changes in parental spending on children, 1972-2007', Demography 50(1), 1-23. https://doi. org/10.1007/s13524-012-0146-4

Leibbrandt, M., Finn, A. \& Woolard, I., 2012, 'Describing and decomposing postapartheid income inequality in South Africa', Development Southern Africa 29(1) 19-34. https://doi.org/10.1080/0376835X.2012.645639

Low, B.S., Parker, N., Hazel, A. \& Welch, K.B., 2013, 'Life expectancy, fertility, and women's lives: A life-history perspective', Cross-Cultural Research: The Journal of Comparative Social Science 47(2), 198-225. https://doi.org/10.1177/1069397112471807

Maag, E., 2013, Child-related benefits in the federal income tax, Urban Institute, Washington, DC

Madden, D. \& Savage, M., 2019, 'Which households matter most? Capturing equity considerations in tax reform via generalised social marginal welfare weights' International Tax and Public Finance 27, 153-193(2020). https://doi.org/10.1007/ s10797-019-09543-y

Maitra, P. \& Ray, R., 2003, 'The effect of transfers on household expenditure patterns and poverty in South Africa', Journal of Development Economics 71(1), 23-49. https://doi.org/10.1016/S0304-3878(02)00132-3

Mangoma, A. \& Wilson-Prangley, A., 2019, 'Black tax: Understanding the financial transfers of the emerging black middle class', Development Southern Africa 36(4), 443-460. https://doi.org/10.1080/0376835X.2018.1516545

Maxfield, M., 2013, The effects of the earned income tax credit on child.

Moffitt, R.A., 2015, 'The deserving poor, the family, and the U.S. welfare system', Demography 52(3), 729-749. https://doi.org/10.1007/s13524-015-0395-0

Molina, J.A., 2013, 'Altruism in the household: in kind transfers in the context of kin selection', Review of Economics of the Household 11(3), 309-312. https://doi. org/10.1007/s11150-013-9214-9

Narayan, S. \& Narayan, P.K., 2013, 'The inflation-output nexus: Empirical evidence from India, South Africa, and Brazil', Research in International Business and Finance 28(1), 19-34. https://doi.org/10.1016/j.ribaf.2012.09.003

Okasha, S. \& Martens, J., 2016, 'The causal meaning of Hamilton's rule', Royal Society Open Science 3(3), 160037. https://doi.org/10.1098/rsos.160037

Port Elizabeth Electric Tramway Company Ltd v CIR (1936 CPD 241)(8 SATC 346).

Potts, R., 2012, 'Social welfare in South Africa: Curing or causing poverty', Penn State Journal of International Affar 2(1), 74-90.

Republic of South Africa, 2020, Rates and monetary amounts and amendment of Revenue Laws Act, 2019 (Act No. 32 of 2019) (Notice 655), Government gazette 42950, January 15, Government Printer, Pretoria.

Seekings, J. \& Moore, E., 2013, Kin, market and state in the provision of care in South Africa.

Seltzer, L.H., 1968, 'The rationale of the personal exemptions', in The personal exemptions in the income tax, pp. 85-129, National Bureau of Economic Reserach, Cambridge.

Spears, D., 2011, 'Economic decision-making in poverty depletes behavioural control', The B.E. Journal of Economic Analysis \& Policy 11(1), 1-44. https://doi. org/10.2202/1935-1682.2973

Statistics South Africa, 2016, Community survey 2016 in brief, Statistics South Africa, Pretoria.

Statistics South Africa, 2019, Financial statistics of national government 2017/2018, Statistics South Africa, Pretoria.

Statistics South Africa, 2020, Quarterly labour force survey quarter 4: 2019, Statistics South Africa, Pretoria.

Svallfors, S., 2012, Contested welfare states, Stanford University Press, Stanford, CA.

Tax Policy Centre, 2020, Tax policy centre briefing book, Urban-Brookings Tax Policy Center, Washington, DC.

Taylor, R.J., Chatters, L.M., Woodward, A.T. \& Brown, E., 2013, 'Racial and ethnic differences in extended family, friendship, fictive kin, and congregational informal support networks', Family Relations 62(4), 609-624.

The World Bank, 2019, GINI index (World Bank estimate), viewed 29 May 2020, from https://data.worldbank.org/indicator/SI.POV.GINI.

Tregenna, F., 2012, 'What are the distributional implications of halving poverty in South Africa when growth alone is not enough?', Applied Economics 44(20) 2577-2596. https://doi.org/10.1080/00036846.2011.566186

United States of America, Department of Treasury, Internal Revenue Service, 2018, Exemptions, Standard Deduction, and Filing Information (2017), Publication 501, Washington, DC, viewed n.d., from https://www.irs.gov/pub/irs-prior/p5012017.pdf.

United States of America, Department of Treasury, Internal Revenue Service, 2020a, Medical and dental expenses, Publication 502, Washington, DC, viewed from https://www.irs.gov/pub/irs-pdf/p502.pdf.

United States of America, Department of Treasury, Internal Revenue Service, 2020b, Tax benefits for education, Publication 970, Washington, DC, viewed from https:// www.irs.gov/pub/irs-pdf/p970.pdf.

Whiting, G., 2009, 'Gifted black males: Understanding and decreasing barriers to achievement and identity', Roeper Review 31(4), 224-233. https://doi.org/10.1080/ 02783190903177598 